\title{
Adrenomedullin and tumour microenvironment
}

\author{
Ignacio M Larráyoz, Sonia Martínez-Herrero, Josune García-Sanmartín, Laura Ochoa-Callejero and Alfredo Martínez*
}

\begin{abstract}
Adrenomedullin (AM) is a regulatory peptide whose involvement in tumour progression is becoming more relevant with recent studies. AM is produced and secreted by the tumour cells but also by numerous stromal cells including macrophages, mast cells, endothelial cells, and vascular smooth muscle cells. Most cancer patients present high levels of circulating AM and in some cases these higher levels correlate with a worst prognosis. In some cases it has been shown that the high AM levels return to normal following surgical removal of the tumour, thus indicating the tumour as the source of this excessive production of AM. Expression of this peptide is a good investment for the tumour cell since AM acts as an autocrine/paracrine growth factor, prevents apoptosis-mediated cell death, increases tumour cell motility and metastasis, induces angiogenesis, and blocks immunosurveillance by inhibiting the immune system. In addition, AM expression gets rapidly activated by hypoxia through a HIF-1a mediated mechanism, thus characterizing AM as a major survival factor for tumour cells. Accordingly, a number of studies have shown that inhibition of this peptide or its receptors results in a significant reduction in tumour progression. In conclusion, AM is a great target for drug development and new drugs interfering with this system are being developed.
\end{abstract}

Keywords: Adrenomedullin, Angiogenesis, Tumour growth, PAMP, Xenograft, CLR, RAMP, Tumour microenvironment

\section{Introduction}

Adrenomedullin (AM) is a regulatory peptide that was first isolated in 1993 from human pheochromocytoma extracts by Kitamura et al. [1]. These authors found that AM was able to stimulate cAMP production in human platelets and exerted a potent and long-lasting hypotensive activity in rats. AM is synthesized both by tumour cells and by normal adrenal medulla cells, as well as by many other tissues [2]. It is a circulating hormone, although it functions also as a local paracrine and autocrine mediator with multiple biological activities such as vasodilatation, cell growth, regulation of hormone secretion, natriuresis, and antimicrobial effects [2-4].

\section{Structure of adrenomedullin}

Human AM is a small hormone of 52 amino acids. It belongs to the amylin/calcitonin gene-related peptide (CGRP) super-family, which also includes CGRP, amylin and intermedin, also named adrenomedullin 2 [5-7]. The $\mathrm{C}$-terminal tyrosine residue is amidated $\left(-\mathrm{CONH}_{2}\right)$ and AM contains a six amino acid ring formed by an internal

\footnotetext{
* Correspondence: amartinezr@riojasalud.es

Oncology Area, Center for Biomedical Research of La Rioja CIBIR, C/Piqueras 98, Logroño 26006, Spain
}

disulfide bond between residues 16 and 21 . Both structural features are essential for its biological activity.

The three-dimensional structure of AM comprises a central $\alpha$-helical region, covering approximately one third of its total length, flanked by two disordered segments. The presence of the $\alpha$-helix at the centre of AM seems to be a general feature of the calcitonin peptide super-family, which is important for the physiology of these peptides and the recognition of their specific receptors [8].

\section{Adrenomedullin gene expression and release}

AM is encoded by the $a d m$ gene, which has been identified in several mammalian species and is located on human chromosome 11p15.4; consisting of four exons and three introns, with TATA, CAAT and GC boxes in the 5 '-flanking region.

The mature AM peptide is derived from preproadrenomedullin, which contains 185 amino acids in humans. After cleaving the 21-residue $\mathrm{N}$-terminal signaling peptide, preproadrenomedullin is converted to proadrenomedullin, which is a precursor of mature AM (amino acids 95-146 of preproadrenomedullin) as well as of another active peptide, proadrenomedullin $\mathrm{N}$-terminal 
20-peptide or PAMP (amino acids 22-41 of preproadrenomedullin) [5].

AM production is mostly regulated by oxidative stress and inflammation-related substances such as lipopolisaccharide and inflammatory cytokines such as TNF- $\alpha$ and IL-1, which increase AM secretion rate. There are several binding sites for activator protein-2 (AP-2) and c-AMP-regulated enhancer element. It has also been discovered that there are nuclear factor-K $\beta$ (NF-K $\beta$ ) sites on the promoter of the AM [2]. Hypoxia is also a potent inducer of AM expression. This overexpression is mediated by transactivation of the AM promoter by hypoxia inducible factor 1 (HIF-1) transcription factor, as well as by posttranscriptional mRNA stabilization. Hypoxia response elements (HREs) have been found in the promoter of the human adm gene [9].

\section{Metabolism of adrenomedullin}

AM is a circulating peptide and it can be found in plasma at a concentration of $2-10 \mathrm{pM}$ in humans. AM is also present in other biological fluids such as urine, saliva, sweat, milk, amniotic fluid and cerebrospinal liquid.

In plasma, AM is specifically bound to adrenomedullin binding protein-1 (AMBP-1), which was later identified as complement factor $\mathrm{H}$ [10]. AM bound to complement factor $\mathrm{H}$ cannot be detected in plasma, so it is thought that total plasma AM could be higher than reported in most studies. Circulating AM is rapidly degraded with a half-life of 16-20 minutes. Matrix metalloproteinase 2 seems to be responsible for the initial degradation of AM, which is followed by an aminopeptidase $[11,12]$.

\section{Adrenomedullin receptors}

Specific binding sites for AM are located in many cell types and tissues such as the heart, lungs, spleen, liver, vas deferens, kidney glomerulus, skeletal muscle, hypothalamus, and spinal cord, among others. The wide distribution of binding sites for AM is related with its great variety of biological functions. In addition, AM is able to bind to many areas of the brain, providing the anatomical basis for the involvement of AM in the physiology of the central nervous system [13].

The AM receptor contains a member of the 7transmembrane domain G-protein-coupled receptor superfamily which is named calcitonin receptor-like receptor (CLR). However, CLR needs the presence of modulating proteins with a single transmembrane domain known as receptor activity modifying proteins (RAMP). Three RAMPs have been identified in the human genome: RAMP1, RAMP2, and RAMP3. RAMPs bind to the CLR in the endoplasmic reticulum promoting transport to the plasma membrane [14].

RAMP1 transports CLR to the membrane surface as a mature glycoprotein, and this heterodimer functions as a
CGRP receptor [14]. The CLR molecules transported by RAMP2 and RAMP3 are core-glycosilated and function as AM receptors (AMR); CLR/RAMP2 is known as $\mathrm{AMR}_{1}$, whereas CLR/RAMP3 is dubbed $\mathrm{AMR}_{2}[5,15]$. It is hypothesized that residues present in RAMP2 and 3 but not in RAMP1 could be able to alter the pharmacology of CLR and be responsible for making CLR/RAMP2 and CLR/RAMP3 AM receptors [16].

The expression of RAMP isoforms in a particular cell may change between physiological and pathological conditions [17], determining the degree of response to AM and CGRP $[18,19]$. In physiological conditions the more abundant isoform is RAMP2. The most robust changes in RAMP expression levels coincide with those situations in which plasma AM level is most elevated, as in pregnancy or diseases like sepsis or heart failure. In those situations, there is an elevation in RAMP3 expression, apparently in order to decrease AM responsiveness [18].

\section{Signal transduction mechanisms}

The signal transduction pathways activated by AM vary between species, organs, tissues, and cells. However, there are three main signaling pathways whereby AM exerts its actions: cAMP, Akt, and mitogen activated protein kinase (MAPK)-extracellular signal regulatedprotein kinase (ERK).

The main signal transduction pathways activated by AM seems to be the adenylyl cyclase/cAMP system. In many cell types, AM and CGRP receptors are coupled to $G_{s}$ proteins that activate adenylate cyclase and increase intracellular levels of cAMP [5]. In bovine aortic endothelial cells and vascular smooth muscle cells (VSMC) the accumulation of cAMP causes the activation of protein kinase A (PKA) which in turn increases calcium $\left(\mathrm{Ca}^{2+}\right)$ efflux leading to relaxation of the vascular cells [20]. Moreover, it was confirmed that AM can induce $\mathrm{Ca}^{2+}$ mobilization independently of cAMP levels. AM activated phospholipase $\mathrm{C}$ through its specific receptor and accelerated inositol-1,4,5- $\mathrm{P}_{3}$ formation to stimulate $\mathrm{Ca}^{2+}$ release from the endoplasmic reticulum intracellular store. In addition, the activation of phospholipase $\mathrm{C}$ is also involved in ion channel opening [20,21]. However, other studies have shown that AM administration does not have any effects in intracellular $\mathrm{Ca}^{2+}$ concentration and even decreases $\mathrm{Ca}^{2+}$ content in cultured human umbilical vein endothelial cells (HUVECs) [22] or in porcine coronary arteries [23]. These results suggest that the regulation of $\mathrm{Ca}^{2+}$ mobilization by $\mathrm{AM}$ may depend on the cell type and physiological context.

Intracellular $\mathrm{Ca}^{2+}$ increases, in response to $\mathrm{AM}$, caused activation of nitric oxide (NO) synthase and $\mathrm{NO}$ release leading to relaxation of cardiac myocytes [24]. AM activation of $\mathrm{NO}$ pathway has a very important role in the regulation of the cardiovascular system by regulating 
blood-flow [25], having a cytoprotective action against ischemia/reperfusion injury and against myocardial ischemia-induced arrhythmias in rats [26]. Furthermore, it has been demonstrated that AM inhibited endothelial cell apoptosis through a NO-dependent pathway [27]. Some authors postulate that NO prevents apoptosis by S-nitrosylating caspases [28-30].

$\mathrm{AM}$ has been shown to activate the PI3K/Akt pathway in vascular endothelial cells where it regulates many steps such as vasodilation, cell survival, proliferation, migration and vascular cord-like structure formation [31]. The specific role of AM in the multistep process of angiogenesis is regulated via a mechanism that requires the activation of the $\mathrm{AMR}_{1}$ and $\mathrm{AMR}_{2}$ receptors [32]. $\mathrm{AM}$ also acts directly on myocardium by the presence of CLR in myocytes, where it enhances neovascularization, induces cardioprotective effects and exerts antiapoptotic effects through the PI3K-dependent pathway after ischemia/reperfusion [33].

The role of AM in growth and mitogenesis has led to investigate the regulation of MAPK by AM. AM appears to either stimulate or inhibit cell proliferation depending on the particular cell type. AM signalling directly promotes endothelial cell growth and survival through activation of MAPK/ERK downstream signalling pathways [34]. Under serum deprivation, AM promotes DNA synthesis and cell proliferation in VSMCs $[35,36]$. These responses are mediated by $\mathrm{p} 42 / \mathrm{p} 44$ MAPK activation. Interestingly, in glomerullar mesangial cells AM causes an opposite effect by increasing apoptosis during serum deprivation [37]. Activation of MAPK and other kinases such as cAMP-PKA, JNK and protein phosphatase 2A (PP2A) have been proposed to mediate the proapoptotic effect of AM in mesangial cells. On the other hand AM protects malignant cells from hypoxia-induced cell death by up-regulation of Bcl-2 in an autocrine/paracrine manner [38].

\section{Physiological activities of adrenomedullin}

All signal mechanisms in which AM is involved are the basis of this peptide's extensive repertoire of biological functions such as vasodilation, cellular proliferation, apoptosis modulation or inflammatory regulation, among others.

The main role played by AM in mammalian development has become apparent following the generation of different knockout (KO) models. In $a d m$ gene $\mathrm{KO}$ mice, in which the expression of AM and PAMP are suppressed, the null phenotype is embryonically lethal due to the scarcity of placental vascularization, malformation of the basement membrane in the aorta and cervical arteries, detachment of the endothelial cells from the basement structure, and the presence of edema [39]. Very recent studies have confirmed these results, demonstrating that locally produced AM in the trophoblast binucleate cells of the bovine placenta may play a crucial role in regulation of placental vascular and cellular functions during pregnancy, especially during transition from the mid to late gestation period [40]. $\mathrm{KO}$ mouse models in which only AM expression, but not PAMP expression, is affected are also embryonic lethal between embryonic day 14 (E14.5) and embryonic day 15 (E15.5) [41]. Thus, AM may be intimately related with embryonic development and pregnancy $[42,43]$.

A gene-targeted $\mathrm{KO}$ model of the CLR gene, Calcrl, demonstrates that Calcrl is also essential for embryo survival. $\mathrm{Calcrl}^{-1-}$ pups are not viable, the embryos die between E13.5 and E14.5 of gestation and they exhibit a very similar phenotype to $\mathrm{AM}^{-/-}$and $\mathrm{AM} / \mathrm{PAMP}^{-/-}$mice [44].

In models of mice lacking RAMP2 the results are similar to the ones shown above. RAMP2 $2^{-/-}$embryos die in utero at midgestation due to severe deformation, vascular fragility, severe edema and hemorrhage [45]. Very recent studies with endothelial cell-specific RAMP2 KO mice (E- RAMP2-/-) have confirmed that the AM-RAMP2 system is a key determinant of vascular integrity and homeostasis from prenatal stages through adulthood [46].

Surprisingly, a complete absence of RAMP3 has no effect on survival. RAMP3-null mice appear normal until old age (9-10 months), at which point they have less weight than their wild-type littermates [47]. These results provide support to the hypothesis that RAMP2 and RAMP3 have distinct physiological functions in embryogenesis, adulthood, and old age.

To continue with the study of the lack of AM in adult tissues and organisms, tissue-specific conditional KO models have been generated using Cre/loxP technology [48].

In the adult organism, AM has been located in many cell types and in most tissues throughout the body [49], including the nervous system and related structures, cardiovascular system, endocrine organs, digestive tube, excretory system, respiratory system, reproductive tract and integument, among others.

AM has a variety of biological actions which are of potential importance for cardiovascular homeostasis, growth and development of cardiovascular tissues and regulation of body fluid [50-53]. Systemic AM administration has demonstrated that this peptide reduces arterial pressure, decreases peripheral vascular resistance, and increases heart rate and cardiac output [54-57]. Moreover, AM and PAMP function as potent angiogenic agents [58], are necessary to maintain the integrity of the mucous membrane's microvasculature [46], and promote a faster healing of epithelial wounds [59-61]. AM binds to specific receptors in endothelial cells and elicits endothelium-dependent vasorelaxation mediated by $\mathrm{NO}$ [62], endothelium-derived hyperpolarizing factor [63], and/or vasodilatory prostanoids [64]. 
AM exerts a tight control on renal function and body fluid volume [65,66], regulating the hypothalamic-pituitaryadrenal axis at all levels [67].

AM regulates hormone secretion in many tissues and organs. Levels of this peptide have effects in the hypothalamic-pituitary-adrenal axis as shown above [67]. In addition, AM is synthesized in pancreatic polypeptide-producing $\mathrm{F}$ cells of the pancreatic islets and $\mathrm{AM}$ receptors are expressed in insulin-producing $\beta$-cells [68]. Several studies have shown that endogenous AM tonically inhibits insulin secretion [68,69].

In the digestive system, $\mathrm{AM}$ immunoreactivity is widely distributed in the mucosal and glandular epithelia of the stomach, esophagus, intestine, gallbladder, bile duct and acini of the pancreas and salivary glands [70]. AM is a potent inhibitor of basal gastrinstimulated $\mathrm{HCl}$ secretion [71].

AM and its receptors are abundantly expressed in the central nervous system and its cellular components $[70,72]$. It plays an important role in the regulation of specific blood-brain barrier properties [73], it also increases the preganglionic sympathetic discharges [74], and it exerts several neuroprotective actions against ischemic damage [75]. In addition, relatively recent studies suggest that AM may be involved in the neuroendocrine response to stress and nociception [76,77].

Finally, AM has been found in all epithelial surfaces which separate the external and internal environment and in all body secretions [78]. This wide distribution suggests the possibility that AM has an immunityrelated function. It has been proven that both $\mathrm{AM}$ and PAMP display potent antimicrobial action against Grampositive and Gram-negative bacteria [3].

\section{Adrenomedullin and disease}

Elevation of AM levels in plasma has been observed for a variety of cardiovascular disorders. Accumulating evidence supports a compensatory role for AM in heart failure [79] and myocardial infarction [80]. It has been established that plasma AM levels increase in patients with heart failure in proportion to the severity of the disease [81]; and they are also increased during acute phase of myocardial infarction reaching its maximum on day 2-3 and returning to baseline after about 3 weeks [80]. Furthermore, recent studies suggest that plasma AM level is an independent prognostic indicator of heart failure $[55,82]$ and $A M$ exerts a protective action against ischemia-reperfusion injury after stroke [55]. It is well established that AM also protects against ischemiareperfusion injury in other organs, such as the kidney [83] or the brain [75].

AM was detected in macrophages found within the atherosclerotic plaque [84]. Plasma AM is increased in patients with chronic ischemic stroke and correlates with the extent of carotid artery atherosclerosis [85]. In theory, AM could inhibit atherogenesis due to its inhibitory effect on migration and proliferation of vascular smooth muscle cells, inhibition of endothelial cell apoptosis and anti-inflammatory activity.

Elevation of plasma AM concentration is also observed in patients with primary arterial hypertension and is higher in individuals with complications of hypertension, such as left ventricular hypertrophy and nephrosclerosis [86]. It is suggested that the up-regulation of cardiac AM system in hypertension is a protective mechanism decreasing myocardial overload due to vasodilatory and natriuretic properties of AM, as well as limiting further myocardial hypertrophy and remodelling [87].

Plasma AM concentration is increased, whereas urinary AM excretion is decreased in various types of glomerulonephritis [88]. In addition, plasma AM progressively increases in patients with chronic renal failure [89].

In septic shock patients, a marked elevation of AM blood levels has been reported, probably as a defensive action [90-92]. However, excessive AM release during septic shock may provoke adverse effects such as hypotension which may threaten the patient's life [3].

AM also plays a role in primary and secondary pulmonary hypertension. Very recent studies in rats with pulmonary hypertension induced by high blood flow suggest that AM exerts a protective action in the development of this pathology, by inhibiting pulmonary procollagen synthesis and alleviating pulmonary artery collagen accumulation [93].

Furthermore, AM has emerged as a novel and promising therapy for digestive pathologies related with inflammation such as gastric ulcers [94] and inflammatory bowel diseases $[95,96]$. This is closely related with the local and systemic anti-inflammatory actions that AM is able to exert $[97,98]$. For example, it has been demonstrated that AM inhibits the secretion of pro-inflammatory cytokines when it is released to the medium by peripheral blood monocytes [5] and plays a role in the evolution of Th1/Th2 cytokines balance, decreasing pro-inflammatory cytokines levels (IL-6, IL-10, TNF- $\alpha$, IFN- $\gamma$ ) [99-101]. In addition to the regulatory role on immune cells, AM also decreases endothelial permeability, thus reducing the formation of inflammatory exudates [5].

The existence of AM in pancreatic islets and its inhibitory effect on insulin secretion suggest that AM may be involved in the pathogenesis of diabetes mellitus. In type 1 diabetes, plasma AM is increased only in patients with microangiopathy. Increased AM may result from endothelial activation and/or impaired renal clearance in subjects with diabetic nephropathy [102]. This suggests that increased AM in type 1 diabetes is a consequence of the disease rather than a causal agent. In humans, the levels of circulating AM are clearly elevated in patients with 
type 2 diabetes when compared to normal controls $[103,104]$. In addition, AM has emerged as a possible biomarker for early diagnosis in pancreatic cancerinduced diabetes [105].

$\mathrm{AM}$ is also involved in many eye pathologies. AM levels in the plasma, vitreous fluid samples and fibrous membrane tissues are all significantly elevated in patients with proliferative diabetic retinopathy compared with control subjects [106]. AM concentration in vitreous fluid is markedly increased in patients with proliferative vitreoretinopathy, the most common complication of retinal detachment originating from the proliferation of retinal pigment cells [107].

\section{Adrenomedullin levels in cancer patients}

There are now many studies that show an association between AM expression and cancer. Initially, these were predominantly studies where plasma AM concentrations were measured in patients suffering from different tumour types and compared with healthy patients. These tumours included bronchial neuroendocrine tumour, clear cell renal cell carcinoma, midgut tumour, osteosarcoma, pancreatic adenocarcinoma, pancreatic insulinoma, aldosterone-producing adenoma, pheochromocytoma, pituitary adenoma, and plexiform neurofibroma [108-118] and there were significant increases of AM levels in all cancer patients.

Interestingly, in patients with osteosarcoma, insulinoma, pheochromocytoma, and primary aldosteronism due to adenoma, elevated blood AM levels decreased following surgery and returned to normal $[109,111,113,114]$, indicating that the tumour was the main source of these excessive AM levels. However, plasma AM levels of patients after 4-5 weeks of surgery of clear cell renal cell carcinoma and of other kidney tumours were similar to presurgery levels. Therefore, plasma AM is not suited as a tumour marker for this disease [118].

Nowadays with the accessibility of molecular techniques, AM mRNA and/or protein expression have also been determined in different tumour types and compared with normal tissue, normal-looking tissue adjacent to the tumour, or with other related no tumoural and pathological tissues. Several clinical studies suggest that AM is overexpressed in numerous tumours including colorectal cancer, bladder urothelial cell carcinoma, chromophobe renal carcinoma, clear-cell renal carcinoma, osteosarcoma, pancreatic adenocarcinoma, insulinoma, ovarian carcinoma, endometrial cancer, leiomyoma, glioma, glioblastoma, neuroblastoma, ganglioneuroblastoma, pituitary adenoma (ACTH-secreting), somatotropinoma, astrocytoma, hepatocellular carcinoma, non-small cell lung carcinoma, squamous cell carcinoma, adenocarcinoma of the lung, bronchial neuroendocrine carcinoma, midgut neuroendocrine carcinoma, pheochromocytoma, aldosterone- producing adenoma, breast cancer, intraocular or orbital tumours, and melanoma, as shown in Table 1 [108-110, 116,118-144]. However, AM expression in the anterior pituitary is diminished in tumours as compared to the normal gland [145]. On the other hand, as described by Letizia et al. [112], blood AM concentrations in control patients was low as compared to the setting of Cushing disease due to pituitary adenoma [112]. These data could be interpreted by an increased release of AM from the secretory granules of the pituitary into circulation. In prostate, no difference on the expression of AM was detected between benign epithelial cells adjacent to prostate adenocarcinoma lesions and tumour [146].

In most tumours a high AM mRNA expression correlated with high protein expression. However, in endometrial cancer tissues and chromophobe renal carcinoma, although AM mRNA levels were high, the protein expression was mild [121,125], indicating complex post-transcriptional regulation.

Furthermore, in some tumours it is possible to correlate plasma levels and expression of AM with disease progression. Plasma levels and AM expression of bronchial neuroendocrine carcinomas and midgut neuroendocrine carcinomas correlate with tumour progression [108]. In breast cancer, AM plasma concentrations correlate with the presence of lymph node metastasis [144]. AM expression is highly correlated with the degree of malignancy and metastasis of osteosarcoma [109]. In patients with leiomyomas, high AM expression is associated with increased vascular density [126]. Epithelial ovarian cancer patients with high AM expression showed a higher incidence of metastasis, larger residual size of tumours after cytoreduction, and shorter disease-free and overall survival time [123]. AM gene expression levels may play a key role in the biology of epithelial ovarian cancer and may define a more aggressive tumour phenotype [124]. However, recent studies performed in ovarian cancer patients by Baranello et al. found high expression levels of AM as a positive prognostic factor [149]. In hepatocellular carcinoma, AM expression was positively correlated with invasion and progression [132,133]. Elevated AM mRNA was associated with high Gleason scores in prostate cancer [153]. High AM mRNA levels were associated with an increased risk of relapse in patients who underwent surgery for localized clear cell renal and colorectal carcinoma [121,147]. In colorectal carcinoma, AM mRNA levels are also a significant factor for poor prognosis and incidence of liver metastasis [147]. The expression of AM is associated with melanomagenesis in melanoma patients [140]. AM mRNA in neuroblastoma is linked to tumour differentiation [143]. The correlation of AM expression and the grade of glioma supports the hypothesis that AM may participate in the progression of the tumour [128]. 
Table 1 Expression of $A M$ and $A M$ receptors in tumours and their role on disease progression

\begin{tabular}{|c|c|c|c|c|c|}
\hline Cancer type & $\begin{array}{l}\text { AM in } \\
\text { plasma* }\end{array}$ & AM expression & Receptor expression & $\mathrm{DP}^{* *}$ & References \\
\hline Breast carcinoma & presence & Prot & & $\begin{array}{l}\text { lymph node } \\
\text { metastasis }\end{array}$ & {$[138,144]$} \\
\hline $\begin{array}{l}\text { Bladder urothelial cell } \\
\text { carcinoma }\end{array}$ & & $>m R N A /$ Prot & & & {$[120]$} \\
\hline \multirow{2}{*}{$\begin{array}{l}\text { Chromophobe renal } \\
\text { carcinoma }\end{array}$} & & $>$ mRNA & & & [121] \\
\hline & & $<$ Prot & & & \\
\hline \multirow[t]{2}{*}{ Clear-cell renal carcinoma } & & $>$ mRNA & CLR and RAMP2 & & {$[118,121]$} \\
\hline & & Prot & & & \\
\hline \multirow[t]{2}{*}{ Colorectal carcinoma } & & $>\mathrm{mRNA}$ & $>$ CLR, RAMP2, RAMP3 & progression & {$[119,147,148]$} \\
\hline & & $>$ Prot & & & \\
\hline Midgut tumour & $>$ & & & progression & {$[108]$} \\
\hline Anaplastic astrocytoma & & $<\mathrm{mRNA}$ & & & {$[128,131]$} \\
\hline Glioma & & $>$ mRNA & & progression & {$[127]$} \\
\hline Glioblastoma & & $>\mathrm{mRNA}$ & $\begin{array}{l}\text { CLR, RAMP2 and } \\
\text { RAMP3 }\end{array}$ & & {$[121,128,131]$} \\
\hline \multirow[t]{2}{*}{ Hepatocellular carcinoma } & & $>\mathrm{mRNA}$ & & invasion and & {$[132,133]$} \\
\hline & & $>$ Prot & & & \\
\hline $\begin{array}{l}\text { Intraocular or orbital } \\
\text { tumours }\end{array}$ & & $>\mathrm{mRNA}$ & & & [139] \\
\hline Leiomyoma & & $>$ Prot & & & {$[126]$} \\
\hline ganglioneuroblastoma & & $>$ Prot & & & [129] \\
\hline \multirow[t]{2}{*}{ Neuroblastoma } & & $>\mathrm{mRNA}$ & & differentiation & {$[129,143]$} \\
\hline & & $>$ Prot & & & \\
\hline $\begin{array}{l}\text { Bronchial neuroendocrine } \\
\text { tumour }\end{array}$ & $>$ & & & progression & {$[108]$} \\
\hline Small cell lung carcinoma & & $<\mathrm{mRNA}$ & & & {$[134,141]$} \\
\hline $\begin{array}{l}\text { Non-small cell lung } \\
\text { carcinoma }\end{array}$ & & $\begin{array}{l}\text { mRNA immunoreactivity was } \\
\text { essentially weak }\end{array}$ & & & {$[134,141]$} \\
\hline $\begin{array}{l}\text { Squamous cell carcinoma } \\
\text { of the lungs }\end{array}$ & & $<\mathrm{mRNA}$ & & & {$[134,141]$} \\
\hline $\begin{array}{l}\text { Adenocarcinoma of the } \\
\text { lung }\end{array}$ & & mRNA & & & {$[134,141]$} \\
\hline Osteosarcoma & $>$ & $>$ mRNA / Prot & & metastasis & [109] \\
\hline \multirow[t]{2}{*}{ Ovarian carcinoma } & & $>$ mRNA / Prot & & over-all survival & {$[123,124,142]$} \\
\hline & & & & $\begin{array}{l}\text { Positive Prognostic } \\
\text { Factor }\end{array}$ & [149] \\
\hline \multirow[t]{2}{*}{ Endometrial carcinoma } & & $>$ mRNA & & progression & {$[125,150]$} \\
\hline & & $<$ Prot & & & \\
\hline Pancreatic adenocarcinoma & $>$ & $>$ AM \&CLR mRNA / Prot & $\begin{array}{l}\text { CLR, RAMP1 and } \\
\text { RAMP2 }\end{array}$ & & {$[110,116,122,151]$} \\
\hline Pancreatic insulinoma & $>$ & $>$ Prot & & & {$[110,111]$} \\
\hline \multirow[t]{2}{*}{ Adrenocortical tumours } & $>$ & mRNA & & & {$[113,135,136]$} \\
\hline & & Prot no detected & & & \\
\hline \multirow[t]{2}{*}{ Pheochromocytoma } & $>$ & mRNA & CLR, RAMP1, RAMP2 & & {$[114,117,129,135-137,152]$} \\
\hline & & $>$ Prot & $a r$ & & \\
\hline Pituytary adenomas & $>$ & $>$ Prot & & progression & {$[112,130,136,145]$} \\
\hline Plexiform neurofibroma & $>$ & & & & {$[115]$} \\
\hline
\end{tabular}




\begin{tabular}{|c|c|c|c|c|}
\hline & & & $\begin{array}{l}\text { biomarker of } \\
\text { transformation }\end{array}$ & \\
\hline Somatotropinoma & $>\mathrm{mRNA}$ & & & Knerr et al., [131]) \\
\hline Prolactinoma & mRNA & & & \\
\hline meningiomas & mRNA & & & \\
\hline Prostate & mRNA & & high Gleason scores & {$[146,153]$} \\
\hline adenocarcinoma & Prot & & & \\
\hline Skin carcinomas & Prot & $\begin{array}{l}>\text { CLR, RAMP2, and } \\
\text { RAMP3 }\end{array}$ & & {$[78,140]$} \\
\hline
\end{tabular}

* >:higher plasma AM concentration in cancer patients than in healthy controls. **DP: Correlation of AM with disease progression.

There is significant evidence for the association of the expression of AM and its receptors with cancer. AM and CLR mRNA levels were higher in pancreatic adenocarcinoma tissues compared to normal pancreatic tissues [116]. The expression levels of AM, CLR, RAMP2 and RAMP3 in human melanoma were higher than in control tissues [140]. Tissue microarray analysis of human colorectal tumours revealed a clear increase of AM, CLR, RAMP2, and RAMP3 staining in lymph nodes and distant metastasis when compared with primary tumours [119]. Recently, new cancer risk markers are being developed. Cheung et al demonstrated that carriers of a single nucleotide polymorphism (SNP), rs4910118, had significantly lower levels of circulating AM than homozygotes for the more common allele [154]. In agreement with this, Martinez-Herrero et al. described that carriers of the rs4910118 SNP have a 4.6-fold lower risk of developing cancer than homozygotes for the major allele [155].

Midregional -proadrenomedullin (MR-proAM) is a stable and reliable surrogate marker for AM release levels. MRproAM was measured in plasma from persons without cancer prior to the baseline exam. During the follow-up median period of 14 years diverse cancer events occurred. In this context, MR-proAM predicts later development of cancer in males, particularly in younger males [156].

\section{Adrenomedullin and tumour microenvironment}

There is an increasing body of evidence suggesting that malignant growth encompasses several processes including increase in growth signals, angiogenesis and metastasis, inhibition of apoptosis, and others [157-159].

Although AM does not cause cancer by itself it can promote its advance through different mechanisms. In addition, known carcinogens such as cigarette smoking can increase AM expression through activation of aryl hydrocarbon receptor (AHR), and blockade of AM can decrease tobacco-induced tumour growth [160]. AM has been shown to be strongly up-regulated in several different tumour types, especially when subjected to hypoxic environments. AM is involved in tumour initiation and progression by promoting cell proliferation, angiogenesis, change of phenotype, and the inhibition of apoptosis [161-164]. In the last years, numerous studies have appeared showing a relation between AM expression and cancer. In most of them, the expression (either mRNA and/or protein) of AM has been compared between normal tissue and different tumour types. In general, the reports show that AM is over-expressed in tumours such as renal cell carcinoma, some endocrinerelated tumours, hepatocellular carcinoma, non-small cell lung carcinoma, and others [19,132,134,165-168]. Interestingly, there are some reports of decreased expression of AM in human pituitary adenomas in comparison with nontumoural adenohypophyses [145].

\section{Adrenomedullin expression in cancer cells and its role on malignant growth}

Over the last years, numerous authors have reported the regulatory properties that AM possesses on the proliferation of a wide variety of cancer cells. In 1996, Miller and cols analyzed the expression of AM mRNA by RTPCR in 20 human normal tissues and 48 tumour cell lines [166]. The authors found that $95 \%$ of normal and tumour cells expressed the mRNA for the peptide [166]. Tumour cell lines evaluated included small cell lung carcinomas, non-small cell lung carcinomas, breast, nervous system (glioblastoma, neuroblastomas), ovarian, prostate, adrenal, chondrosarcoma, and chronic monocytic leukemia [166]. These data have been replicated on different tumour cell lines such as pancreatic cell lines (PANC1, L3.6, HPAFII, SU86.86) [110,116,169], gliomas $[170,171]$, prostate cancer cell lines [162,172-175], ovarian cancer [149,176,177], osteosarcoma [109], renal carcinoma [121,178], multiple myeloma [179], bladder urothelial cell carcinoma [120], pituitary adenomas [145], colorectal cancer $[119,147,148]$, breast cancer [144], endometrial cancer [38], hepatocellular carcinoma [132] and others.

It is noteworthy to mention that, in some tumours, RAMP3 is expressed alongside RAMP2 while in others only RAMP2 is present. In renal tumours, for instance, 
RAMP2 was expressed in the tumour cells themselves, while RAMP3 elevation was found in inflammatory cells associated with the tumour, highlighting the importance of the interaction of the tumour with the microenvironment [121].

Interestingly, Lombardero and cols reported that the expression of AM measured by immunohistochemistry in various hormone-secreting pituitary adenomas was found to be diminished as compared to nontumoural adenohypophyses [145], although this fact may represent a faster disregulated secretion of the peptide to the blood stream.

\section{Adrenomedullin expression is increased under hypoxic conditions}

Focal areas of hypoxia are inherent to the environment of solid tumours [180,181]. Decreased oxygen availability is one of the driving forces of cancer survival and progression. When tumour cells are exposed to hypoxic conditions, an oxygen-sensing mechanism, based on the hypoxia-inducible factor-1 (HIF-1), mediates the expression of a group of genes that help tumour cells to survive $[9,182,183]$. Several studies have addressed the regulation of AM (and its receptors) expression under hypoxic conditions in a variety of tumour tissues and cell lines. The first authors to report an induction of $\mathrm{AM}$ in a tumour cell line exposed to hypoxia were Nakayama and cols in 1998 [184]. Human colorectal carcinoma cells exposed to a reduced oxygen tension showed a time-dependent increase in AM mRNA and peptide expression. Later on, the hypoxia-induced upregulation of AM expression was described in a variety of human tumour cell lines from lung, breast, ovary, prostate, bone, blood [9], multiple myeloma [179], bladder urothelial cell carcinoma [120], colorectal carcinoma $[119,147,148]$ and hepatocellular carcinoma [132], among others. The first proof that this increased expression was mediated by HIF-1 was provided by Garayoa and cols [9] using HIF- $1 \alpha$ and HIF-1 $\beta$ knockout cell lines.

As an example to illustrate the effect of AM in hypoxic environments we can compare the role that AM plays in the pathophysiology of pilocytic astrocytomas and glioblastomas. Pilocytic astrocytoma is a slowly growing tumour where preexisting blood vessels are sufficient to provide enough oxygen and to ensure tumour growth [171]. Glioblastoma, however, is a rapidly growing tumour where normal blood supply is not sufficient, leading to necrosis and hypoxia [171]. Real-time quantitative RT-PCR was used to study expression of AM, RAMP2, RAMP3, and CLR in pilocytic astrocytoma and glioblastoma. Interestingly, although there were not differences in RAMP2 or RAMP3 expression, AM mRNA expression was induced in glioblastoma whereas it was barely detectable in pilocytic astrocytoma when subjected to hypoxic conditions. Furthermore, AM and VEGF mRNA expression were highly correlated, supporting the view that AM may function as an autocrine/paracrine growth factor for glioblastoma cells subjected to hypoxia [171].

\section{Adrenomedullin is a survival factor for tumour cells}

Adrenomedullin is able to reduce apoptosis of both endothelial and tumour cells. AM-overexpressing endometrial tumour cells, prostate cancer cells, or breast carcinoma cells present reduced levels of proapoptotic proteins such as fragmented PARP, Bax, and activated caspases, resulting in lower level of induced-apoptosis compared with control cells $[165,172,185]$. However, the up-regulation of AM in tumours can be used to design strategies to treat these types of cancer. For instance, AM expression up-regulated the expression of IL13 receptor $\alpha 2$ which can be used to increase the sensitivity to IL13PE cytotoxin (consisting of IL-13 and a truncated form of Pseudomonas exotoxin) [175].

AM can stimulate cell growth and inhibit apoptosis in a variety of tumour cells, including prostate cancer $[172,174,175]$, ovarian cancer $[149,176]$, osteosarcoma [109], renal carcinoma [178], bladder carcinoma [120], breast cancer [186], colorectal cancer [119,148], gliomas [170], and hepatocellular carcinoma [132].

Thus, when AM was overexpressed in the endometrial cancer cell line RL95.2 a marked growth increase was seen in response to hypoxia-induced apoptosis [38]. Similarly, T47D and MCF-7 breast tumour cell lines challenged with serum-free conditions were able to maintain cell proliferation only in the presence of AM [165]. Also, the implication of AM in the survival of U87 glioblastoma cells was demonstrated by intratumoural administration of an anti-AM antibody in xenografted mice which resulted in a $70 \%$ decrease in xenograft weight and density of tumour vessels.

The role of AM in prostate cancer cell pathophysiology seems to be controversial. Depending on the cell line used (PC-3, DU145, or LNCap) and the insult (etoposide or serum deprivation) the effect of AM on proliferation/apoptosis differs [172,173]. After serum deprivation, AM prevented apoptosis in DU145 and PC3 cells, but not in LNCaP cells $[172,173]$. However, after treatment with etoposide, AM prevented apoptosis in PC-3 and LNCaP cells, but not in DU145 cells [172,173]. Surprisingly, although PC-3 prostate cancer cells overexpressing AM generated smaller tumours in vivo when injected in nude mice [172], blockade of AM by an specific antibody in DU145 prostate cancer cells induced a clear regression of tumour growth and metastasis in a xenograft mouse model [174].

As noted above, the presence of AM peptide, as well as AM receptors, has been described in ovarian cancer cells [178]. Silencing of the AM gene inhibited the 
proliferation and increased the chemosensitivity of HO8910 cells by downregulation of Bcl-2 and p-ERK, as described for other cancer cell types [176]. However, other authors have reported that AM effect in ovarian cancer cells is weak as revealed by proliferation assays and cell cycle analysis performed under stressing conditions, such as serum starvation and/or hypoxia [149]. Baranello and cols found that AM was a survival factor for HEY cells but not for A2780 or OVCAR-3 ovarian cancer cells. Furthermore, a clinical study revealed that high expression of AM was linked to a positive outcome, suggesting that the use of AM antagonists could be deleterious in the treatment of ovarian cancer patients [149].

Although the expression of AM, CLR, RAMP1, and RAMP2 mRNA has been reported in several pancreatic cancer cells, RAMP3 mRNA expression could only be found in 1 of 5 cell lines studied [116]. These observations, and the strong colocalization of CLR with RAMP1/RAMP2 but not with RAMP3, indicate that RAMP1/2 but not RAMP3 are the main coreceptors for CLR in pancreatic adenocarcinoma [116]. Intratumoural injection of AM antagonist peptides or transfer of naked DNA encoding AM antagonists induce the regression of a pancreatic cancer cell line and a breast cancer cell line in a mouse xenograft [169]. In addition to its role regulating proliferation/apoptosis, the blockade of AM action seems to also involve a reduction in tumoural neovascularization, which is entirely inhibited in AMA (adrenomedullin antagonist)-treated mice [169].

The role of AM in cell growth and invasion in human colorectal tumours has also been explored recently. Human colon carcinoma cells (HT-29, HCT116, DLD1, and SW480) express AM, CLR, RAMP2, and RAMP3, and the expression of AM is increased under hypoxic conditions $[119,147,148]$. Addition of synthetic AM to tumour cells in culture stimulated cell proliferation and invasion which could be reversed by co-incubation with an AM antibody or an AM antagonist [119,148]. Furthermore, AM antibody treatment significantly reduced the growth of HT-29 tumour xenografts in mice [119]. These data seem to correlate well with clinical data where AM has been described as an independent prognostic factor for colorectal cancer [147].

In recent years numerous xenografted tumour models have been used to provide new insights in the understanding of AM's role in tumour growth in vivo. Interestingly, vascular density or directed growth of blood vessels measured in these xenograft models correlates well with AM expression. Thus, human endometrial, breast, lung or pancreatic tumour cell lines overexpressing AM show an increase in blood vessel density $[38,165,169,187,188]$, while colorectal, prostate, and renal carcinoma cells with decreased AM availability resulted in blood vessel density reduction $[119,148,174,189]$. Similar results were obtained when xenografting human glioblastoma cells, who express high basal levels of AM. Both density of blood vessels and cell growth were decreased when an antibody against AM was administered intratumourally [128].

All these data taken together support the idea that AM functions as a potent autocrine/paracrine growth factor for tumour cells and demonstrate that reduction of endogenous AM, either pharmacologically or by gene therapy, can potentially impair tumour growth in vivo. The collective findings point out that the autocrine loop formed by AM and its receptors plays a major role in tumour formation and progression, and that it may be a target for new treatments against malignant diseases.

\section{Adrenomedullin in extra-tumoural components}

Stromal factors interact with cancer cells to establish a microenvironment that supports tumour growth and survival. AM is an autocrine/paracrine peptide produced by stromal and cancer cells to support such a microenvironment [149]. AM enhances blood and lymphatic angiogenesis, providing necessary nutrients and oxygen to the tumour cells to grow and, eventually, to disseminate $[9,34,149]$. The main sources of AM are the vascular endothelium and, usually, the tumour cells themselves, although other types of cells such as mast cells, macrophages and fibroblasts can also produce the peptide $[138,140]$. The role of AM in tumourigenic angiogenesis has been studied using several in vitro, xenograft, and knockout mouse models [38,165,168,185]. AM can regulate the tumour microenvironment by promoting proliferation and migration of endothelial cells, reducing the activity of the immune system by reducing cytokine secretion [3], and inhibiting the complement pathway $[168,183]$. Experiments using AM knockout mice demonstrated that AM is essential for vascular morphogenesis in normal animals $[39,188,190]$, as well as in tumours. In fact, AM is not only able to enhance bone marrowderived mononuclear cell differentiation into endothelial cells but also it is important for the formation of mature vessels [191].

\section{Adrenomedullin and cancer treatment}

Several strategies have been proposed to inhibit AMinduced tumour growth, including AM mRNA rybozyme which modulates AM expression, and other approaches targeting AM binding to its receptor for example anti-AM blocking antibodies, small nonpeptide molecules, receptor antagonists, truncated peptides, e.g. AM22-52 (AMA) and PAMP12-20 [167,192].

Various studies using human tumour xenografts in immuno-deficient mice have shown that lowering AM levels reduces tumour growth. For example, growth of sarcoma tumours was slower when injected in heterozygotic 
AM knockout mice as compared to their wild type counterparts. In addition, treatment of tumours with a competitive inhibitor of AM (AMA) resulted in tumour reduction [193]. Besides, tumour weight was reduced following intra-tumoural injection of an AM antagonist (AMA) in mouse models of pancreatic [169,187], mammary [169], and skin [140] cancer cell growth. Furthermore, a single intra-tumoural or intra-muscular transfer of naked DNA-encoding AMA suppresses renal cell carcinoma growth [189].

Moreover, targeting AM receptors (AMR) with systemic delivery of neutralizing antibodies inhibits growth of human tumour xenografts in mice. Antibodies against AMR significantly reduced the growth of glioblastoma [53,128], lung [53], prostate [174], colon tumours [53,119], and melanoma [140] growth in vivo. Although some authors have raised concerns about the specificity of the antibodies against the receptors [194], the original authors performed pre-absorption tests that resulted in successful band suppression showing at least immunological specificity against synthetic peptides used as antigens [32,53]. Nevertheless, more studies from other laboratories are needed to completely characterize these antibodies and to confirm originally obtained results.

Other strategies targeting AM includes RNA interference that reduced the growth of human bladder urothelial cell carcinoma [120]. In addition, the peptide fragment PAMP (12-20) diminished tumour growth in a xenograft model using lung carcinoma [195].

Obviously none of these potential treatments has undergone pre-clinical and clinical testing and nothing is known about potential side effects and/or toxicity in humans. Therefore we must be careful with the interpretation of previous data until clinical trials have been performed.

\section{Conclusion}

All these studies support the idea of AM as a survival factor for tumour cells, that can be produced either by the tumour itself or by a number of stromal cells surrounding the tumour. In general, AM expression is upregulated by hypoxia, a common occurrence in tumours, and the excessive production of this peptide results in poorer prognosis for the patients. Therefore, new therapies based on the blockade of the AM autocrine/paracrine system are been developed and some of them are very effective in animal models. It remains to be seen whether this efficacy would persist in clinical trials.

\section{Competing interests}

The authors declare that they have no competing interests.

\section{Authors' contributions}

IML, SM-H, JG-S, LO-C, and AM conceived the review, and participated in its design and coordination and helped to draft the manuscript. All authors read and approved the final manuscript.

\section{Acknowledgements}

This work was funded by a grant from the Instituto de Salud Carlos III (PI13/02166)

Received: 1 July 2014 Accepted: 21 November 2014

Published online: 05 December 2014

\section{References}

1. Kitamura K, Kangawa K, Kawamoto M, Ichiki Y, Nakamura S, Matsuo H, Eto T: Adrenomedullin: a novel hypotensive peptide isolated from human pheochromocytoma. Biochem Biophys Res Commun 1993, 192:553-560.

2. Hinson JP, Kapas S, Smith DM: Adrenomedullin, a multifunctional regulatory peptide. Endocr Rev 2000, 21:138-167.

3. Zudaire E, Portal-Nunez S, Cuttitta F: The central role of adrenomedullin in host defense. J Leukoc Biol 2006, 80:237-244.

4. Lopez J, Martinez A: Cell and molecular biology of the multifunctional peptide, adrenomedullin. Int Rev Cytol 2002, 221:1-92.

5. Beltowski J, Jamroz A: Adrenomedullin-what do we know 10 years since its discovery? Pol J Pharmacol 2004, 56:5-27.

6. Takei Y, Inoue K, Ogoshi M, Kawahara T, Bannai H, Miyano S: Identification of novel adrenomedullin in mammals: a potent cardiovascular and renal regulator. FEBS Lett 2004, 556:53-58.

7. Roh J, Chang CL, Bhalla A, Klein C, Hsu SY: Intermedin is a calcitonin/ calcitonin gene-related peptide family peptide acting through the calcitonin receptor-like receptor/receptor activity-modifying protein receptor complexes. J Biol Chem 2004, 279:7264-7274.

8. Perez-Castells J, Martin-Santamaria S, Nieto L, Ramos A, Martinez A, de Pascual-Teresa B, Jimenez-Barbero J: Structure of micelle-bound adrenomedullin: a first step toward the analysis of its interactions with receptors and small molecules. Biopolymers 2012, 97:45-53.

9. Garayoa M, Martinez A, Lee S, Pio R, An WG, Neckers L, Trepel J, Montuenga LM, Ryan H, Johnson R, Gassmann M, Cuttitta F: Hypoxia-inducible factor-1 (HIF-1) up-regulates adrenomedullin expression in human tumor cell lines during oxygen deprivation: a possible promotion mechanism of carcinogenesis. Mol Endocrinol 2000, 14:848-862.

10. Pio R, Elsassr TH, Martinez A, Cuttitta F: Identification, characterization, and physiological actions of factor $\mathrm{H}$ as an adrenomedullin binding protein present in human plasma. Microsc Res Tech 2002, 57:23-27.

11. Dupuis J, Caron A, Ruël N: Biodistribution, plasma kinetics and quantification of single-pass pulmonary clearance of adrenomedullin. Clin Sci (Lond) 2005, 109:97-102.

12. Martinez A, Oh HR, Unsworth EJ, Bregonzio C, Saavedra JM, Stetler-Stevenson WG, Cuttitta F: Matrix metalloproteinase-2 cleavage of adrenomedullin produces a vasoconstrictor out of a vasodilator. Biochem J 2004, 383:413-418.

13. Juaneda C, Dumont $Y$, Chabot JG, Fournier A, Quirion R: Adrenomedullin receptor binding sites in rat brain and peripheral tissues. Eur J Pharmacol 2003, 474:165-174

14. Poyner DR, Sexton PM, Marshall I, Smith DM, Quirion R, Born W, Muff R, Fischer JA, Foord SM: International Union of Pharmacology. XXXII. The mammalian calcitonin gene-related peptides, adrenomedullin, amylin, and calcitonin receptors. Pharmacol Rev 2002, 54:233-246.

15. McLatchie LM, Fraser NJ, Main MJ, Wise A, Brown J, Thompson N, Solari R, Lee MG, Foord SM: RAMPs regulate the transport and ligand specificity of the calcitonin-receptor-like receptor. Nature 1998, 393:333-339.

16. Qi T, Christopoulos G, Bailey RJ, Christopoulos A, Sexton PM, Hay DL: Identification of $\mathrm{N}$-terminal receptor activity-modifying protein residues important for calcitonin gene-related peptide, adrenomedullin, and amylin receptor function. Mol Pharmacol 2008, 74:1059-1071.

17. Jacob A, Wu R, Wang P: Regulation of RAMP expression in diseases. Adv Exp Med Biol 2012, 744:87-103.

18. Gibbons C, Dackor R, Dunworth W, Fritz-Six K, Caron KM: Receptor activity-modifying proteins: RAMPing up adrenomedullin signaling Mol Endocrinol 2007, 21:783-796.

19. Nikitenko LL, Leek R, Henderson S, Pillay N, Turley H, Generali D, Gunningham S, Morrin HR, Pellagatti A, Rees MC, Harris AL, Fox SB: The $\mathrm{G}$-protein-coupled receptor CLR is upregulated in an autocrine loop with adrenomedullin in clear cell renal cell carcinoma and associated with poor prognosis. Clin Cancer Res 2013, 19:5740-5748.

20. Shimekake Y, Nagata K, Ohta S, Kambayashi Y, Teraoka H, Kitamura K, Eto T, Kangawa K, Matsuo H: Adrenomedullin stimulates two signal transduction 
pathways, CAMP accumulation and Ca2+ mobilization, in bovine aortic endothelial cells. J Biol Chem 1995, 270:4412-4417.

21. Szokodi I, Kinnunen $P$, Tavi P, Weckström M, Tóth M, Ruskoaho H: Evidence for CAMP-independent mechanisms mediating the effects of adrenomedullin, a new inotropic peptide. Circulation 1998, 97:1062-1070

22. Hippenstiel S, Witzenrath M, Schmeck B, Hocke A, Krisp M, Krüll M, Seybold J, Seeger W, Rascher W, Schütte H, Suttorp N: Adrenomedullin reduces endothelial hyperpermeability. Circ Res 2002, 91:618-625.

23. Kureishi Y, Kobayashi S, Nishimura J, Nakano T, Kanaide H: Adrenomedullin decreases both cytosolic $\mathrm{Ca} 2+$ concentration and $\mathrm{Ca}(2+)$-sensitivity in pig coronary arterial smooth muscle. Biochem Biophys Res Commun 1995, 212:572-579.

24. Ikeda U, Kanbe T, Kawahara Y, Yokoyama M, Shimada K: Adrenomedullin augments inducible nitric oxide synthase expression in cytokine-stimulated cardiac myocytes. Circulation 1996, 94:2560-2565.

25. Shimosawa T, Matsui H, Xing G, Itakura K, Ando K, Fujita T: Organ-protective effects of adrenomedullin. Hypertens Res 2003, 26(Suppl):S109-S112.

26. Looi YH, Kane KA, McPhaden AR, Wainwright CL: Adrenomedullin acts via nitric oxide and peroxynitrite to protect against myocardial ischaemia-induced arrhythmias in anaesthetized rats. Br J Pharmacol 2006, 148:599-609.

27. Sata M, Kakoki M, Nagata D, Nishimatsu H, Suzuki E, Aoyagi T, Sugiura S, Kojima H, Nagano T, Kangawa K, Matsuo H, Omata M, Nagai R, Hirata Y: Adrenomedullin and nitric oxide inhibit human endothelial cell apoptosis via a cyclic GMP-independent mechanism. Hypertension 2000, 36:83-88.

28. Mannick JB, Miao XQ, Stamler JS: Nitric oxide inhibits Fas-induced apoptosis. J Biol Chem 1997, 272:24125-24128.

29. Rössig L, Fichtlscherer B, Breitschopf K, Haendeler J, Zeiher AM, Mülsch A, Dimmeler S: Nitric oxide inhibits caspase-3 by S-nitrosation in vivo. $J$ Biol Chem 1999, 274:6823-6826.

30. Sinz EH, Kochanek PM, Dixon CE, Clark RS, Carcillo JA, Schiding JK, Chen M, Wisniewski SR, Carlos TM, Williams D, DeKosky ST, Watkins SC, Marion DW, Billiar TR: Inducible nitric oxide synthase is an endogenous neuroprotectant after traumatic brain injury in rats and mice. J Clin Invest 1999, 104:647-656

31. Nishimatsu H, Suzuki E, Nagata D, Moriyama N, Satonaka H, Walsh K, Sata M, Kangawa K, Matsuo H, Goto A, Kitamura T, Hirata Y: Adrenomedullin induces endothelium-dependent vasorelaxation via the phosphatidylinosito 3-kinase/Akt-dependent pathway in rat aorta. Circ Res 2001, 89:63-70.

32. Fernandez-Sauze S, Delfino C, Mabrouk K, Dussert C, Chinot O, Martin PM, Grisoli F, Ouafik L, Boudouresque F: Effects of adrenomedullin on endothelial cells in the multistep process of angiogenesis: involvement of CRLR/RAMP2 and CRLR/RAMP3 receptors. Int J Cancer 2004, 108:797-804.

33. Okumura H, Nagaya N, Itoh T, Okano I, Hino J, Mori K, Tsukamoto Y, Ishibashi-Ueda H, Miwa S, Tambara K, Toyokuni S, Yutani C, Kangawa K: Adrenomedullin infusion attenuates myocardial ischemia/reperfusion injury through the phosphatidylinositol 3-kinase/Akt-dependent pathway. Circulation 2004, 109:242-248

34. Fritz-Six KL, Dunworth WP, Li M, Caron KM: Adrenomedullin signaling is necessary for murine lymphatic vascular development. J Clin Invest 2008, 118:40-50.

35. Iwasaki H, Eguchi S, Shichiri M, Marumo F, Hirata Y: Adrenomedullin as a novel growth-promoting factor for cultured vascular smooth muscle cells: role of tyrosine kinase-mediated mitogen-activated protein kinase activation. Endocrinology 1998, 139:3432-3441.

36. Iwasaki H, Shichiri M, Marumo F, Hirata Y: Adrenomedullin stimulates proline-rich tyrosine kinase 2 in vascular smooth muscle cells. Endocrinology 2001, 142:564-572.

37. Parameswaran N, Nambi P, Brooks DP, Spielman WS: Regulation of glomerular mesangial cell proliferation in culture by adrenomedullin. Eur J Pharmacol 1999, 372:85-95.

38. Oehler MK, Norbury C, Hague S, Rees MC, Bicknell R: Adrenomedullin inhibits hypoxic cell death by upregulation of $\mathrm{BCl}-2$ in endometrial cancer cells: a possible promotion mechanism for tumour growth. Oncogene 2001, 20:2937-2945.

39. Shindo T, Kurihara $Y$, Nishimatsu $H$, Moriyama N, Kakoki M, Wang $Y$, Imai Y, Ebihara A, Kuwaki T, Ju KH, Minamino N, Kangawa K, Ishikawa T, Fukuda M, Akimoto $Y$, Kawakami H, Imai T, Morita H, Yazaki Y, Nagai R, Hirata Y, Kurihara H: Vascular abnormalities and elevated blood pressure in mice lacking adrenomedullin gene. Circulation 2001, 104:1964-1971.
40. Hayashi KG, Hosoe M, Sakumoto R, Takahashi T: Temporo-spatial expression of adrenomedullin and its receptors in the bovine placenta. Reprod Biol Endocrinol 2013, 11:62. 10.1186/1477-7827-1111-1162.

41. Shimosawa T, Shibagaki $Y$, Ishibashi K, Kitamura K, Kangawa K, Kato S, Ando K, Fujita T: Adrenomedullin, an endogenous peptide, counteracts cardiovascular damage. Circulation 2002, 105:106-111.

42. Garayoa M, Bodegas E, Cuttitta F, Montuenga LM: Adrenomedullin in mammalian embryogenesis. Microsc Res Tech 2002, 57:40-54

43. Lenhart PM, Caron KM: Adrenomedullin and pregnancy: perspectives from animal models to humans. Trends Endocrinol Metab 2012, 23:524-532. doi:510.1016/j.tem.2012.1002.1007. Epub 2012 Mar 1016.

44. Dackor RT, Fritz-Six K, Dunworth WP, Gibbons CL, Smithies O, Caron KM: Hydrops fetalis, cardiovascular defects, and embryonic lethality in mice lacking the calcitonin receptor-like receptor gene. Mol Cell Biol 2006, 26:2511-2518

45. Ichikawa-Shindo Y, Sakurai T, Kamiyoshi A, Kawate H, linuma N, Yoshizawa T, Koyama T, Fukuchi J, limuro S, Moriyama N, Kawakami H, Murata T, Kangawa K, Nagai R, Shindo T: The GPCR modulator protein RAMP2 is essential for angiogenesis and vascular integrity. J Clin Invest 2008, 118:29-39.

46. Koyama T, Ochoa-Callejero L, Sakurai T, Kamiyoshi A, Ichikawa-Shindo Y, linuma N, Arai T, Yoshizawa T, lesato Y, Lei Y, Uetake R, Okimura A, Yamauchi A, Tanaka M, Igarashi K, Toriyama Y, Kawate H, Adams RH, Kawakami H, Mochizuki N, Martinez A, Shindo T: Vascular endothelial adrenomedullin-RAMP2 system is essential for vascular integrity and organ homeostasis. Circulation 2013, 127:842-853.

47. Dackor R, Fritz-Six K, Smithies O, Caron K: Receptor activity-modifying proteins 2 and 3 have distinct physiological functions from embryogenesis to old age. J Biol Chem 2007, 282:18094-18099.

48. Plück $A$ : Conditional mutagenesis in mice: the Cre/loxP recombination system. Int J Exp Pathol 1996, 77:269-278.

49. Julian M, Cacho M, Garcia MA, Martin-Santamaria S, de Pascual-Teresa B, Ramos A, Martinez A, Cuttitta F: Adrenomedullin: a new target for the design of small molecule modulators with promising pharmacological activities. Eur J Med Chem 2005, 40:737-750

50. Chen S, Lu X, Zhao Q, Wang L, Li H, Huang J: Association of adrenomedullin gene polymorphisms and blood pressure in a Chinese population. Hypertens Res 2013, 36:74-78.

51. Hasbak P, Sheykhzade M, Schifter S, Edvinsson L: Potentiated adrenomedullin induced vasorelaxation during hypoxia in organ cultured porcine coronary arteries. J Cardiovasc Pharmacol 2014, 63:58-67.

52. Kono T, Kaneko A, Omiya Y, Ohbuchi K, Ohno N, Yamamoto M: Epithelial transient receptor potential ankyrin 1 (TRPA1)-dependent adrenomedullin upregulates blood flow in rat small intestine. Am $J$ Physiol-Gastrointest Liver Physiol 2013, 304:G428-G436.

53. Kaafarani I, Fernandez-Sauze S, Berenguer C, Chinot O, Delfino C, Dussert C, Metellus P, Boudouresque F, Mabrouk K, Grisoli F, Figarella-Branger D, Martin PM, Ouafik L: Targeting adrenomedullin receptors with systemic delivery of neutralizing antibodies inhibits tumor angiogenesis and suppresses growth of human tumor xenografts in mice. FASEB J 2009, 23:3424-3435.

54. Nicholls MG: Hemodynamic and hormonal actions of adrenomedullin. Braz J Med Biol Res 2004, 37:1247-1253.

55. Nishikimi T, Kuwahara K, Nakagawa Y, Kangawa K, Nakao K: Adrenomedullin in cardiovascular disease: a useful biomarker, its pathological roles and therapeutic application. Curr Protein Pept Sci 2013, 14:256-267.

56. Cam Etoz B, Isbil Buyukcoskun N, Ozluk K: Cardiovascular effects of the intracerebroventricular injection of adrenomedullin: roles of the peripheral vasopressin and central cholinergic systems. Braz J Med Biol Res 2012, 45:250-255. Epub 2012 Mar 2011.

57. Kataoka Y, Miyazaki S, Yasuda S, Nagaya N, Noguchi T, Yamada N, Morii I, Kawamura A, Doi K, Miyatake K, Tomoike H, Kangawa K: The first clinical pilot study of intravenous adrenomedullin administration in patients with acute myocardial infarction. J Cardiovasc Pharmacol 2010, 56:413-419.

58. Martinez A: A new family of angiogenic factors. Cancer Lett 2006, 236:157-163.

59. Garcia-Honduvilla N, Cifuentes A, Manuel Bellon J, Bujan J, Martinez A: The angiogenesis promoter, proadrenomedullin N-terminal 20 peptide (PAMP), improves healing in both normoxic and ischemic wounds either alone or in combination with autologous stem/progenitor cells. Histol Histopathol 2013, 28:115-125.

60. Garcia-Honduvilla N, Cifuentes A, Bellon JM, Bujan J, Martinez A: The angiogenesis promoter, proadrenomedullin $\mathrm{N}$-terminal 20 peptide 
(PAMP), improves healing in both normoxic and ischemic wounds either alone or in combination with autologous stem/progenitor cells. Histol Histopathol 2013, 28:115-125.

61. Harada K, Yamahara K, Ohnishi S, Otani K, Kanoh H, Ishibashi-Ueda H, Minamino N, Kangawa K, Nagaya N, Ikeda T: Sustained-release adrenomedullin ointment accelerates wound healing of pressure ulcers. Regul Pept 2011, 168:21-26.

62. Hayakawa H, Hirata Y, Kakoki M, Suzuki Y, Nishimatsu H, Nagata D, Suzuki E, Kikuchi K, Nagano T, Kangawa K, Matsuo H, Sugimoto T, Omata M: Role of nitric oxide-cGMP pathway in adrenomedullin-induced vasodilation in the rat. Hypertension 1999, 33:689-693.

63. Wangensteen R, Quesada A, Sainz J, Duarte J, Vargas F, Osuna A: Role of endothelium-derived relaxing factors in adrenomedullin-induced vasodilation in the rat kidney. Eur J Pharmacol 2002, 444:97-102.

64. Yang BC, Lippton H, Gumusel B, Hyman A, Mehta JL: Adrenomedullin dilates rat pulmonary artery rings during hypoxia: role of nitric oxide and vasodilator prostaglandins. J Cardiovasc Pharmacol 1996, 28:458-462

65. Jougasaki M, Wei CM, Aarhus LL, Heublein DM, Sandberg SM, Burnett JC: Renal localization and actions of adrenomedullin: a natriuretic peptide. Am J Physiol 1995, 268:F657-F663.

66. Samson WK: Adrenomedullin and the control of fluid and electrolyte homeostasis. Annu Rev Physiol 1999, 61:363-389.

67. Nishikimi T: Adrenomedullin in the kidney-renal physiological and pathophysiological roles. Curr Med Chem 2007, 14:1689-1699.

68. Zudaire E, Cuttitta F, Martínez A: Regulation of pancreatic physiology by adrenomedullin and its binding protein. Regul Pept 2003, 112:121-130.

69. Hayashi M, Tojo A, Shimosawa T, Fujita T: The role of adrenomedullin in the renal NADPH oxidase and (pro)renin in diabetic mice. J Diabetes Res 2013, 2013:134395

70. Marutsuka K, Hatakeyama K, Sato Y, Yamashita A, Sumiyoshi A, Asada Y: Immunohistological localization and possible functions of adrenomedullin. Hypertens Res 2003, 26(Suppl):S33-S40.

71. Rossowski WJ, Cheng BL, Jiang NY, Coy DH: Examination of somatostatin involvement in the inhibitory action of GIP, GLP-1, amylin and adrenomedullin on gastric acid release using a new SRIF antagonist analogue. Br J Pharmacol 1998, 125:1081-1087.

72. Serrano J, Alonso D, Fernandez AP, Encinas JM, Lopez JC, Castro-Blanco S, Fernandez-Vizarra P, Richart A, Santacana M, Uttenthal LO, Bentura ML, Martinez-Murillo R, Martinez A, Cuttitta F, Rodrigo J: Adrenomedullin in the central nervous system. Microsc Res Tech 2002, 57:76-90.

73. Kis B, Abrahám CS, Deli MA, Kobayashi H, Niwa M, Yamashita H, Busija DW, Ueta Y: Adrenomedullin, an autocrine mediator of blood-brain barrier function. Hypertens Res 2003, 26(Suppl):S61-S70.

74. Saita M, Shimokawa A, Kunitake T, Kato K, Hanamori T, Kitamura K, Eto T, Kannan H: Central actions of adrenomedullin on cardiovascular parameters and sympathetic outflow in conscious rats. Am J Physiol 1998, 274:R979-R984.

75. Miyashita K, Itoh H, Arai H, Suganami T, Sawada N, Fukunaga Y, Sone M, Yamahara K, Yurugi-Kobayashi T, Park K, Oyamada N, Taura D, Tsujimoto H, Chao TH, Tamura N, Mukoyama M, Nakao K: The neuroprotective and vasculo-neuro-regenerative roles of adrenomedullin in ischemic brain and its therapeutic potential. Endocrinology 2006, 147:1642-1653.

76. Fernandez AP, Serrano J, Tessarollo L, Cuttitta F, Martinez A: Lack of adrenomedullin in the mouse brain results in behavioral changes, anxiety, and lower survival under stress conditions. Proc Natl Acad Sci U S A 2008, 105:12581-12586.

77. Fernandez AP, Serrano J, Martinez-Murillo R, Martinez A: Lack of adrenomedullin in the central nervous system results in apparently paradoxical alterations on pain sensitivity. Endocrinology 2010, 151:4908-4915.

78. Martinez A, Elsasser TH, Muro-Cacho C, Moody TW, Miller MJ, Macri CJ, Cuttitta F: Expression of adrenomedullin and its receptor in normal and malignant human skin: a potential pluripotent role in the integument. Endocrinology 1997, 138:5597-5604.

79. Nishikimi T, Yoshihara F, Mori Y, Kangawa K, Matsuoka H: Cardioprotective effect of adrenomedullin in heart failure. Hypertens Res 2003, 26(Suppl):S121-S127.

80. Kobayashi K, Kitamura K, Hirayama N, Date H, Kashiwagi T, Ikushima I, Hanada Y, Nagatomo Y, Takenaga M, Ishikawa T, Imamura T, Koiwaya Y, Eto T: Increased plasma adrenomedullin in acute myocardial infarction. Am Heart J 1996, 131:676-680.

81. Wong HK, Cheung TT, Cheung BM: Adrenomedullin and cardiovascular diseases. JRSM Cardiovasc Dis 2012, 1(5).
82. Iqbal N, Alim KS, Aramin H, lqbal F, Green E, Higginbotham E, Maisel AS: Novel biomarkers for heart failure. Expert Rev Cardiovasc Ther 2013, 11:1155-1169

83. Nishimatsu H, Hirata Y, Shindo T, Kurihara H, Kakoki M, Nagata D, Hayakawa H, Satonaka H, Sata M, Tojo A, Suzuki E, Kangawa K, Matsuo H, Kitamura T, Nagai R: Role of endogenous adrenomedullin in the regulation of vascular tone and ischemic renal injury: studies on transgenic/knockout mice of adrenomedullin gene. Circ Res 2002, 90:657-663.

84. Nakayama M, Takahashi K, Murakami O, Murakami H, Sasano H, Shirato K, Shibahara S: Adrenomedullin in monocytes and macrophages: possible involvement of macrophage-derived adrenomedullin in atherogenesis. Clin Sci (Lond) 1999, 97:247-251.

85. Shinomiya K, Ohmori K, Ohyama H, Hosomi N, Takahashi T, Osaka K, Kohno $\mathrm{M}$ : Association of plasma adrenomedullin with carotid atherosclerosis in chronic ischemic stroke. Peptides 2001, 22:1873-1880.

86. Kohno M, Hanehira T, Kano H, Horio T, Yokokawa K, Ikeda M, Minami M, Yasunari K, Yoshikawa J: Plasma adrenomedullin concentrations in essential hypertension. Hypertension 1996, 27:102-107.

87. Kato J, Kitamura K, Matsui E, Tanaka M, Ishizaka Y, Kita T, Kangawa K, Eto T: Plasma adrenomedullin and natriuretic peptides in patients with essential or malignant hypertension. Hypertens Res 1999, 22:61-65.

88. Kinoshita H, Fujimoto S, Kitamura K, Matsuura Y, Uezono S, Hisanaga S, Eto T: Increased plasma levels of mature adrenomedullin in chronic glomerulonephritis. Nephron 2000, 86:333-338.

89. Hirose T, Totsune K, Mori N, Mori T, Morimoto R, Metoki H, Asayama K, Kikuya M, Ohkubo T, Kohzuki M, Takahashi K, Imai Y: Expression of adrenomedullin 2/intermedin, a possible reno-protective peptide, is decreased in the kidneys of rats with hypertension or renal failure. Am J Physiol Renal Physiol 2010, 299:F128-F134.

90. Chen YX, Li CS: Prognostic value of adrenomedullin in septic patients in the ED. Am J Emerg Med 2013, 31:1017-1021.

91. Chen YX, Li CS: The predictive value of adrenomedullin for development of severe sepsis and septic shock in emergency department. Biomed Res Int 2013, 2013:960101.

92. Oncel MY, Erdeve O, Uras N, Dilmen U: Is pro-adrenomedullin a more useful marker in hospitalized infants with sepsis? Eur J Pediatr 2014 173:127-128.

93. Pang L, Qi J, Gao Y, Jin H, Du J: Adrenomedullin alleviates pulmonary artery collagen accumulation in rats with pulmonary hypertension induced by high blood flow. Peptides 2014, 54:101-107.

94. Fukuda K, Tsukada H, Oya M, Onomura M, Kodama M, Nakamura H, Hosokawa M, Seino Y: Adrenomedullin promotes epithelial restitution of rat and human gastric mucosa in vitro. Peptides 1999, 20:127-132.

95. Ashizuka S, Kita T, Inatsu H, Kitamura K: Adrenomedullin: a novel therapy for intractable ulcerative colitis. Inflamm Bowel Dis 2013, 19:E26-E27.

96. Ashizuka S, Inatsu H, Kita T, Kitamura K: The first clinical pilot study of adrenomedullin therapy in refractory ulcerative colitis: the initial Six cases. Gastroenterology 2012, 142:S353-S353.

97. Rulle S, Ah Kioon MD, Asensio C, Mussard J, Ea HK, Boissier MC, Liote F, Falgarone G: Adrenomedullin, a neuropeptide with immunoregulatory properties induces semi-mature tolerogenic dendritic cells. Immunology 2012, 136:252-264. doi:210.1111/j.1365-2567.2012.03577.x.

98. Talero E, Di Paola R, Mazzon E, Esposito E, Motilva V, Cuzzocrea S: Anti-inflammatory effects of adrenomedullin on acute lung injury induced by Carrageenan in mice. Mediators Inflamm 2012, $2012: 717851$. doi:10.1155/2012/717851. Epub 712012 May 717820.

99. Ashizuka S, Ishikawa N, Kato J, Yamaga J, Inatsu H, Eto T, Kitamura K: Effect of adrenomedullin administration on acetic acid-induced colitis in rats. Peptides 2005, 26:2610-2615. Epub 2005 Jun 2623.

100. Ashizuka S, Inagaki Ohara K, Kuwasako K, Kato J, Inatsu H, Kitamura K: Adrenomedullin treatment reduces intestinal inflammation and maintains epithelial barrier function in mice administered dextran sulphate sodium. Microbiol Immunol 2009, 53:573-581. doi:510.1111/j.13480421.2009.00159.x

101. Talero E, Sanchez Fidalgo S, De La Lastra CA, Illanes M, Calvo JR, Motilva V: Acute and chronic responses associated with adrenomedullin administration in experimental colitis. Peptides 2008, 29:2001-2012. doi:2010.1016/j.peptides.2008.2007.2013. Epub 2008 Jul 2029.

102. García-Unzueta MT, Montalbán C, Pesquera C, Berrazueta JR, Amado JA: Plasma adrenomedullin levels in type 1 diabetes. Relationship with clinical parameters. Diabetes Care 1998, 21:999-1003. 
103. Lim SC, Morgenthaler NG, Subramaniam T, Wu YS, Goh SK, Sum CF: The relationship between adrenomedullin, metabolic factors, and vascular function in individuals with type 2 diabetes. Diabetes Care 2007 30:1513-1519.

104. Martínez A, Elsasser TH, Bhathena SJ, Pío R, Buchanan TA, Macri CJ, Cuttitta F: Is adrenomedullin a causal agent in some cases of type 2 diabetes? Peptides 1999, 20:1471-1478.

105. Sah RP, Nagpal SJ, Mukhopadhyay D, Chari ST: New insights into pancreatic cancer-induced paraneoplastic diabetes. Nat Rev Gastroentero Hepatol 2013, 10:423-433.

106. Lu Y, Xu Y, Tang C: Changes in adrenomedullin in patients with proliferative diabetic retinopathy. Curr Eye Res 2011, 36:1047-1052.

107. Udono-Fujimori R, Udono T, Totsune K, Tamai M, Shibahara S, Takahashi K: Adrenomedullin in the eye. Regul Pept 2003, 112:95-101.

108. Pavel ME, Hoppe S, Papadopoulos T, Linder V, Mohr B, Hahn EG, Lohmann $\mathrm{T}$, Schuppan D: Adrenomedullin is a novel marker of tumor progression in neuroendocrine carcinomas. Horm Metab Res 2006, 38:112-118.

109. Dai X, Ma W, He XJ, Jha RK: Elevated expression of adrenomedullin is correlated with prognosis and disease severity in osteosarcoma. Med Oncol 2013, 30:347.

110. Aggarwal G, Ramachandran V, Javeed N, Arumugam T, Dutta S, Klee GG Klee EW, Smyrk TC, Bamlet W, Han JJ, Rumie Vittar NB, de Andrade M, Mukhopadhyay D, Petersen GM, Fernandez-Zapico ME, Logsdon CD, Chari ST: Adrenomedullin is up-regulated in patients with pancreatic cancer and causes insulin resistance in beta cells and mice. Gastroenterology 2012, 143:1510-1517. e1511.

111. Letizia C, Tamburrano G, Alo P, Paoloni A, Caliumi C, Marinoni E, Di lorio R, D'Erasmo E: Adrenomedullin, a new peptide, in patients with insulinoma. Eur J Endocrinol 2001, 144:517-520.

112. Letizia C, Di lorio R, De Toma G, Marinoni E, Cerci S, Celi M, Subioli S, D'Erasmo E: Circulating adrenomedullin is increased in patients with corticotropin-dependent Cushing's syndrome due to pituitary adenoma. Metabolism 2000, 49:760-763.

113. Letizia C, De Toma G, Cerci S, Massa R, Coassin S, Subioli S, Scuro L, De Ciocchis A: Adrenomedullin levels are high in primary aldosteronism due to adenoma and decline after surgical cure. Blood Press 1998, 7:19-23.

114. Letizia C, De Toma G, Caliumi C, Cerci S, Massa R, Loria RD, Alo P, Marinoni EM, Diacinti D, D'Erasmo E: Plasma adrenomedullin concentrations in patients with adrenal pheochromocytoma. Horm Metab Res 2001, 33:290-294.

115. Hummel TR, Jessen WJ, Miller SJ, Kluwe L, Mautner VF, Wallace MR, Lazaro C, Page GP, Worley PF, Aronow BJ, Schorry EK, Ratner N: Gene expression analysis identifies potential biomarkers of neurofibromatosis type 1 including adrenomedullin. Clin Cancer Res 2010, 16:5048-5057.

116. Keleg S, Kayed H, Jiang X, Penzel R, Giese T, Buchler MW, Friess H, Kleeff J: Adrenomedullin is induced by hypoxia and enhances pancreatic cancer cell invasion. Int J Cancer 2007, 121:21-32

117. Cotesta D, Caliumi C, Alo P, Petramala L, Reale MG, Masciangelo R, Signore A, Cianci R, D'Erasmo E, Letizia C: High plasma levels of human chromogranin A and adrenomedullin in patients with pheochromocytoma. Tumori 2005, 91:53-58.

118. Michelsen J, Thiesson H, Walter S, Ottosen PD, Skott O, Jensen BL: Tissue expression and plasma levels of adrenomedullin in renal cancer patients. Clin Sci (Lond) 2006, 111:61-70.

119. Nouguerede E, Berenguer C, Garcia S, Bennani B, Delfino C, Nanni I, Dahan L, Gasmi M, Seitz JF, Martin PM, Ouafik L: Expression of adrenomedullin in human colorectal tumors and its role in cell growth and invasion in vitro and in xenograft growth in vivo. Cancer Med 2013, 2:196-207.

120. Liu AG, Zhang XZ, Li FB, Zhao YL, Guo YC, Yang RM: RNA interference targeting adrenomedullin induces apoptosis and reduces the growth of human bladder urothelial cell carcinoma. Med Oncol 2013, 30:616.

121. Deville JL, Bartoli C, Berenguer C, Fernandez-Sauze S, Kaafarani I, Delfino C, Fina F, Salas S, Muracciole X, Mancini J, Lechevallier E, Martin PM, FigarellaBranger D, Ouafik L, Daniel L: Expression and role of adrenomedullin in renal tumors and value of its mRNA levels as prognostic factor in clear-cell renal carcinoma. Int J Cancer 2009, 125:2307-2315.

122. Logsdon CD, Simeone DM, Binkley C, Arumugam T, Greenson JK, Giordano TJ, Misek DE, Kuick R, Hanash S: Molecular profiling of pancreatic adenocarcinoma and chronic pancreatitis identifies multiple genes differentially regulated in pancreatic cancer. Cancer Res 2003, 63:2649-2657.
123. Deng B, Zhang S, Miao Y, Han Z, Zhang X, Wen F, Zhang Y:

Adrenomedullin expression in epithelial ovarian cancers and promotes HO8910 cell migration associated with upregulating integrin alpha5beta1 and phosphorylating FAK and paxillin. J Exp Clin Cancer Res 2012, 31:19

124. Hata K, Takebayashi Y, Akiba S, Fujiwaki R, lida K, Nakayama K, Nakayama S, Fukumoto M, Miyazaki K: Expression of the adrenomedullin gene in epithelial ovarian cancer. Mol Hum Reprod 2000, 6:867-872.

125. Evans JJ, Chitcholtan K, Dann JM, Guilford P, Harris G, Lewis LK, Nagase J, Welkamp AA, Zwerus R, Sykes PH: Adrenomedullin interacts with VEGF in endometrial cancer and has varied modulation in tumours of different grades. Gynecol Oncol 2012, 125:214-219.

126. Hague S, Zhang L, Oehler MK, Manek S, MacKenzie IZ, Bicknell R, Rees MC: Expression of the hypoxically regulated angiogenic factor adrenomedullin correlates with uterine leiomyoma vascular density. Clin Cancer Res 2000, 6:2808-2814.

127. Carlson MR, Pope WB, Horvath S, Braunstein JG, Nghiemphu P, Tso CL, Mellinghoff I, Lai A, Liau LM, Mischel PS, Dong J, Nelson SF, Cloughesy TF: Relationship between survival and edema in malignant gliomas: role of vascular endothelial growth factor and neuronal pentraxin 2. Clin Cancer Res 2007, 13:2592-2598.

128. Ouafik L, Sauze $S$, Boudouresque F, Chinot O, Delfino C, Fina F, Vuaroqueaux V, Dussert C, Palmari J, Dufour H, Grisoli F, Casellas P, Brunner N, Martin PM: Neutralization of adrenomedullin inhibits the growth of human glioblastoma cell lines in vitro and suppresses tumor xenograft growth in vivo. Am J Pathol 2002, 160:1279-1292.

129. Satoh F, Takahashi K, Murakami O, Totsune K, Sone M, Ohneda M, Abe K, Miura $Y$, Hayashi $Y$, Sasano H: Adrenomedullin in human brain, adrenal glands and tumor tissues of pheochromocytoma, ganglioneuroblastoma and neuroblastoma. J Clin Endocrinol Metab 1995, 80:1750-1752.

130. Murakami O, Takahashi K, Satoh F, Totsune K, Sone M, Arihara Z, Andoh N, Mouri T: Expression of adrenomedullin and adrenomedullin mRNA in ectopic ACTH-secreting tumors. Eur J Endocrinol 1998, 138:436-439.

131. Knerr I, Schuster S, Nomikos P, Buchfelder M, Dotsch J, Schoof E, Fahlbusch R, Rascher W: Gene expression of adrenomedullin, leptin, their receptors and neuropeptide $Y$ in hormone-secreting and non-functioning pituitary adenomas, meningiomas and malignant intracranial tumours in humans. Neuropathol Appl Neurobiol 2001, 27:215-222.

132. Park SC, Yoon JH, Lee JH, Yu SJ, Myung SJ, Kim W, Gwak GY, Lee SH, Lee SM, Jang JJ, Suh KS, Lee HS: Hypoxia-inducible adrenomedullin accelerates hepatocellular carcinoma cell growth. Cancer Lett 2008, 271:314-322.

133. Nakata T, Seki N, Miwa S, Kobayashi A, Soeda J, Nimura Y, Kawasaki S, Miyagawa S: Identification of genes associated with multiple nodules in hepatocellular carcinoma using cDNA microarray: multicentric occurrence or intrahepatic metastasis? Hepatogastroenterol 2008, 55:865-872.

134. Martinez A, Miller MJ, Unsworth EJ, Siegfried JM, Cuttitta F: Expression of adrenomedullin in normal human lung and in pulmonary tumors. Endocrinology 1995, 136:4099-4105.

135. Liu J, Kahri Al, Heikkila P, Voutilainen R: Adrenomedullin gene expression and its different regulation in human adrenocortical and medullary tumors. J Endocrinol 1997, 155:483-490.

136. Takahashi K, Satoh F, Sone M, Totsune K, Arihara Z, Noshiro T, Mouri T, Murakami $O$ : Expression of adrenomedullin mRNA in adrenocortical tumors and secretion of adrenomedullin by cultured adrenocortical carcinoma cells. Peptides 1998, 19:1719-1724.

137. Satoh F, Takahashi K, Murakami O, Totsune K, Sone M, Ohneda M, Abe K, Miura $Y$, Mouri T: Immunoreactive adrenomedullin in human adrenal glands and adrenal tumors. Cancer Detect Prev 1997, 21:51-54.

138. Zudaire E, Martinez A, Garayoa M, Pio R, Kaur G, Woolhiser MR, Metcalfe DD, Hook WA, Siraganian RP, Guise TA, Chirgwin JM, Cuttitta F: Adrenomedullin is a cross-talk molecule that regulates tumor and mast cell function during human carcinogenesis. Am J Pathol 2006, 168:280-291.

139. Udono T, Totsune K, Takahashi K, Abe T, Sato M, Shibahara S, Tamai M Increased expression of adrenomedullin mRNA in the tissues of intraocular and orbital tumors. Am J Ophthalmol 2000, 129:555-556.

140. Chen $P$, Huang $Y$, Bong R, Ding $Y$, Song N, Wang $X$, Song $X$, Luo $Y$ : Tumor-associated macrophages promote angiogenesis and melanoma growth via adrenomedullin in a paracrine and autocrine manner. Clin Cancer Res 2011, 17:7230-7239. 
141. Buyukberber S, Sari I, Camci C, Buyukberber NM, Sevinc A, Turk HM: Adrenomedullin expression does not correlate with survival in lung cancer. Med Oncol 2007, 24:245-249.

142. Liu J, Butzow R, Hyden-Granskog C, Voutilainen R: Expression of adrenomedullin in human ovaries, ovarian sex cord-stromal tumors and cultured granulosa-luteal cells. Gynecol Endocrinol 2009, 25:96-103.

143. Dotsch J, Harmjanz A, Christiansen H, Hanze J, Lampert F, Rascher W: Gene expression of neuronal nitric oxide synthase and adrenomedullin in human neuroblastoma using real-time PCR. Int J Cancer 2000, 88:172-175.

144. Oehler MK, Fischer DC, Orlowska-Volk M, Herrle F, Kieback DG, Rees MC, Bicknell R: Tissue and plasma expression of the angiogenic peptide adrenomedullin in breast cancer. Br J Cancer 2003, 89:1927-1933.

145. Lombardero M, Kovacs K, Horvath E, Scheithauer BW, Rotondo F, Salehi F, Lloyd RV: Adrenomedullin expression in pituitary adenomas and nontumoral adenohypophyses. Histol Histopathol 2008, 23:11-17.

146. Sion-Vardy N, Tzikinovsky A, Bolotyn A, Segal S, Fishman D: Augmented expression of chromogranin $A$ and serotonin in peri-malignant benign prostate epithelium as compared to adenocarcinoma. Pathol Res Pract 2004, 200:493-499.

147. Uemura M, Yamamoto H, Takemasa I, Mimori K, Mizushima T, Ikeda M, Sekimoto M, Doki Y, Mori M: Hypoxia-inducible adrenomedullin in colorectal cancer. Anticancer Res 2011, 31:507-514.

148. Wang L, Gala M, Yamamoto M, Pino MS, Kikuchi H, Shue DS, Shirasawa S, Austin TR, Lynch MP, Rueda BR, Zukerberg LR, Chung DC: Adrenomedullin is a therapeutic target in colorectal cancer. Int J Cancer 2014, 134:2041-2050.

149. Baranello C, Mariani M, Andreoli M, Fanelli M, Martinelli E, Ferrandina G, Scambia G, Shahabi S, Ferlini C: Adrenomedullin in ovarian cancer: foe in vitro and friend in vivo? PLOS One 2012, 7:e40678.

150. Michishita M, Minegishi T, Abe K, Kangawa K, Kojima M, lbuki Y: Expression of adrenomedullin in the endometrium of the human uterus. Obstet Gynecol 1999, 93:66-70.

151. Ramachandran V, Arumugam T, Hwang RF, Greenson JK, Simeone DM Logsdon CD: Adrenomedullin is expressed in pancreatic cancer and stimulates cell proliferation and invasion in an autocrine manner via the adrenomedullin receptor, ADMR. Cancer Res 2007, 67:2666-2675.

152. Thouennon E, Pierre A, Tanguy Y, Guillemot J, Manecka DL, Guerin M, Ouafik L, Muresan M, Klein M, Bertherat J, Lefebvre H, Plouin PF, Yon L, Anouar $Y$ : Expression of trophic amidated peptides and their receptors in benign and malignant pheochromocytomas: high expression of adrenomedullin RDC1 receptor and implication in tumoral cell survival. Endocr Relat Cancer 2010, 17:637-651.

153. Rocchi P, Boudouresque F, Zamora AJ, Muracciole X, Lechevallier E, Martin PM, Ouafik L: Expression of adrenomedullin and peptide amidation activity in human prostate cancer and in human prostate cancer cell lines. Cancer Res 2001, 61:1196-1206.

154. Cheung BM, Ong KL, Tso AW, Leung RY, Cherny SS, Sham PC, Lam TH, Lam KS: Plasma adrenomedullin level is related to a single nucleotide polymorphism in the adrenomedullin gene. Eur J Endocrinol 2011, 165:571-577.

155. Martinez-Herrero S, Martinez A: Cancer protection elicited by a single nucleotide polymorphism close to the adrenomedullin gene. J Clin Endocrinol Metab 2013, 98:E807-E810.

156. Belting M, Almgren P, Manjer J, Hedblad B, Struck J, Wang TJ, Bergmann A, Melander $O$ : Vasoactive peptides with angiogenesis-regulating activity predict cancer risk in males. Cancer Epidemiol Biomarkers Prev 2012, 21:513-522.

157. Avraamides CJ, Garmy-Susini B, Varner JA: Integrins in angiogenesis and lymphangiogenesis. Nat Rev Cancer 2008, 8:604-617.

158. Cairns RA, Harris IS, Mak TW: Regulation of cancer cell metabolism. Nat Rev Cancer 2011, 11:85-95.

159. Wouters BG, Koritzinsky M: Hypoxia signalling through mTOR and the unfolded protein response in cancer. Nat Rev Cancer 2008, 8:851-864.

160. Portal-Nunez S, Shankavaram UT, Rao M, Datrice N, Atay S, Aparicio M, Camphausen KA, Fernandez-Salguero PM, Chang H, Lin P, Schrump DS, Garantziotis S, Cuttitta F, Zudaire E: Aryl hydrocarbon receptor-induced adrenomedullin mediates cigarette smoke carcinogenicity in humans and mice. Cancer Res 2012, 72:5790-5800.

161. Albertin G, Forneris M, Aragona F, Nussdorfer GG: Expression of adrenomedullin and its receptors in the human adrenal cortex and aldosteronomas. Int J Mol Med 2001, 8:423-426.

162. Berenguer C, Boudouresque F, Dussert C, Daniel L, Muracciole X, Grino M, Rossi D, Mabrouk K, Figarella-Branger D, Martin PM, Ouafik L:
Adrenomedullin, an autocrine/paracrine factor induced by androgen withdrawal, stimulates 'neuroendocrine phenotype' in LNCaP prostate tumor cells. Oncogene 2008, 27:506-518.

163. Forneris M, Gottardo L, Albertin G, Malendowicz LK, Nussdorfer GG: Expression and function of adrenomedullin and its receptors in Conn's adenoma cells. Int J Mol Med 2001, 8:675-679.

164. Martinez A: Biology of adrenomedullin. Introduction. Microsc Res Tech 2002, 57:1-2.

165. Martinez A, Vos M, Guedez L, Kaur G, Chen Z, Garayoa M, Pio R, Moody T, Stetler-Stevenson WG, Kleinman HK, Cuttitta F: The effects of adrenomedullin overexpression in breast tumor cells. J Natl Cancer Inst 2002, 94:1226-1237.

166. Miller MJ, Martinez A, Unsworth EJ, Thiele CJ, Moody TW, Elsasser T, Cuttitta F: Adrenomedullin expression in human tumor cell lines. Its potential role as an autocrine growth factor. J Biol Chem 1996, 271:23345-23351.

167. Nikitenko LL, Fox SB, Kehoe S, Rees MC, Bicknell R: Adrenomedullin and tumour angiogenesis. Br J Cancer 2006, 94:1-7.

168. Nikitenko LL, MacKenzie IZ, Rees MC, Bicknell R: Adrenomedullin is an autocrine regulator of endothelial growth in human endometrium. Mol Hum Reprod 2000, 6:811-819.

169. Miseki T, Kawakami H, Natsuizaka M, Darmanin S, Cui HY, Chen J, Fu Q, Okada F, Shindo M, Higashino F, Asaka M, Hamuro J, Kobayashi M: Suppression of tumor growth by intra-muscular transfer of naked DNA encoding adrenomedullin antagonist. Cancer Gene Ther 2007, 14:39-44.

170. Benes L, Kappus C, McGregor GP, Bertalanffy H, Mennel HD, Hagner S: The immunohistochemical expression of calcitonin receptor-like receptor (CRLR) in human gliomas. J Clin Pathol 2004, 57:172-176.

171. Metellus P, Voutsinos-Porche B, Nanni-Metellus I, Colin C, Fina F, Berenguer C, Dussault N, Boudouresque F, Loundou A, Intagliata D, Chinot O, Martin PM, Figarella-Branger D, Ouafik L: Adrenomedullin expression and regulation in human glioblastoma, cultured human glioblastoma cell lines and pilocytic astrocytoma. Eur J Cancer 2011, 47:1727-1735.

172. Abasolo I, Montuenga LM, Calvo A: Adrenomedullin prevents apoptosis in prostate cancer cells. Regul Pept 2006, 133:115-122.

173. Abasolo I, Wang Z, Montuenga LM, Calvo A: Adrenomedullin inhibits prostate cancer cell proliferation through a CAMP-independent autocrine mechanism. Biochem Biophys Res Commun 2004, 322:878-886.

174. Berenguer-Daize C, Boudouresque F, Bastide C, Tounsi A, Benyahia Z, Acunzo J, Dussault N, Delfino C, Baeza N, Daniel L, Cayol M, Rossi D, El Battari A, Bertin D, Mabrouk K, Martin PM, Ouafik L: Adrenomedullin blockade suppresses growth of human hormone-independent prostate tumor xenograft in mice. Clin Cancer Res 2013, 19:6138-6150.

175. Joshi BH, Leland P, Calvo A, Green JE, Puri RK: Human adrenomedullin up-regulates interleukin-13 receptor alpha2 chain in prostate cancer in vitro and in vivo: a novel approach to sensitize prostate cancer to anticancer therapy. Cancer Res 2008, 68:9311-9317.

176. Chen $P$, Pang $X$, Zhang $Y$, He $Y$ : Effect of inhibition of the adrenomedullin gene on the growth and chemosensitivity of ovarian cancer cells. Oncol Rep 2012, 27:1461-1466.

177. Zhang $Y$, Zhang S, Shang $H$, Pang $X$, Zhao $Y$ : Basic fibroblast growth factor upregulates adrenomedullin expression in ovarian epithelial carcinoma cells via JNK-AP-1 pathway. Regul Pept 2009, 157:44-50.

178. Giacalone PL, Vuaroqueaux V, Daures JP, Houafic L, Martin PM, Laffargue F, Maudelonde T: Expression of adrenomedullin in human ovaries, ovarian cysts and cancers. Correlation with estrogens receptor status. Eur J Obstet Gynecol Reprod Biol 2003, 110:224-229.

179. Kocemba KA, van Andel H, de Haan-Kramer A, Mahtouk K, Versteeg R, Kersten MJ, Spaargaren M, Pals ST: The hypoxia target adrenomedullin is aberrantly expressed in multiple myeloma and promotes angiogenesis. Leukemia 2013, 27:1729-1737

180. Brown JM, Giaccia AJ: The unique physiology of solid tumors: opportunities (and problems) for cancer therapy. Cancer Res 1998, 58:1408-1416.

181. Genbacev O, Zhou Y, Ludlow JW, Fisher SJ: Regulation of human placental development by oxygen tension. Science 1997, 277:1669-1672.

182. Wenger RH, Gassmann M: Oxygen(es) and the hypoxia-inducible factor-1. Biol Chem 1997, 378:609-616.

183. Zudaire E, Martinez A, Cuttitta F: Adrenomedullin and cancer. Regul Pept 2003, 112:175-183

184. Nakayama M, Takahashi K, Murakami O, Shirato K, Shibahara S: Induction of adrenomedullin by hypoxia and cobalt chloride in human colorectal carcinoma cells. Biochem Biophys Res Commun 1998, 243:514-517. 
185. Oehler MK, Hague S, Rees MC, Bicknell R: Adrenomedullin promotes formation of xenografted endometrial tumors by stimulation of autocrine growth and angiogenesis. Oncogene 2002, 21:2815-2821.

186. Brekhman V, Lugassie J, Zaffryar-Eilot S, Sabo E, Kessler O, Smith V, Golding H, Neufeld G: Receptor activity modifying protein-3 mediates the protumorigenic activity of lysyl oxidase-like protein-2. FASEB J 2011, 25:55-65.

187. Ishikawa T, Chen J, Wang J, Okada F, Sugiyama T, Kobayashi T, Shindo M, Higashino F, Katoh H, Asaka M, Kondo T, Hosokawa M, Kobayashi M: Adrenomedullin antagonist suppresses in vivo growth of human pancreatic cancer cells in SCID mice by suppressing angiogenesis. Oncogene 2003, 22:1238-1242.

188. Karpinich NO, Kechele DO, Espenschied ST, Willcockson HH, Fedoriw Y Caron KM: Adrenomedullin gene dosage correlates with tumor and lymph node lymphangiogenesis. FASEB J 2013, 27:590-600.

189. Tsuchiya K, Hida K, Hida Y, Muraki C, Ohga N, Akino T, Kondo T, Miseki T, Nakagawa K, Shindoh M, Harabayashi T, Shinohara N, Nonomura K, Kobayashi M: Adrenomedullin antagonist suppresses tumor formation in renal cell carcinoma through inhibitory effects on tumor endothelial cells and endothelial progenitor mobilization. Int J Oncol 2010, 36:1379-1386.

190. Caron KM, Smithies O: Extreme hydrops fetalis and cardiovascular abnormalities in mice lacking a functional Adrenomedullin gene. Proc Natl Acad Sci U S A 2001, 98:615-619.

191. Iwase T, Nagaya N, Fujii T, Itoh T, Ishibashi-Ueda H, Yamagishi M, Miyatake K, Matsumoto T, Kitamura S, Kangawa K: Adrenomedullin enhances angiogenic potency of bone marrow transplantation in a rat model of hindlimb ischemia. Circulation 2005, 111:356-362.

192. Martinez A, Julian M, Bregonzio C, Notari L, Moody TW, Cuttitta F: Identification of vasoactive nonpeptidic positive and negative modulators of adrenomedullin using a neutralizing antibody-based screening strategy. Endocrinology 2004, 145:3858-3865.

193. limuro S, Shindo T, Moriyama N, Amaki T, Niu P, Takeda N, Iwata H, Zhang Y, Ebihara A, Nagai R: Angiogenic effects of adrenomedullin in ischemia and tumor growth. Circ Res 2004, 95:415-423.

194. Hay DL, Walker CS, Poyner DR: Adrenomedullin and calcitonin gene-related peptide receptors in endocrine-related cancers: opportunities and challenges. Endocr Relat Cancer 2011, 18:C1-C14.

195. Martinez A, Zudaire E, Portal-Nunez S, Guedez L, Libutti SK, StetlerStevenson WG, Cuttitta F: Proadrenomedullin NH2-terminal 20 peptide is a potent angiogenic factor, and its inhibition results in reduction of tumor growth. Cancer Res 2004, 64:6489-6494.

doi:10.1186/s12967-014-0339-2

Cite this article as: Larráyoz et al:: Adrenomedullin and tumour microenvironment. Journal of Translational Medicine 2014 12:339.

\section{Submit your next manuscript to BioMed Central and take full advantage of:}

- Convenient online submission

- Thorough peer review

- No space constraints or color figure charges

- Immediate publication on acceptance

- Inclusion in PubMed, CAS, Scopus and Google Scholar

- Research which is freely available for redistribution

Submit your manuscript at www.biomedcentral.com/submit
Biomed Central 